\title{
The reporting of the influenza pandemic, 1918-1920 in Hamilton, Ontario
}

\author{
John Rankin \\ Department of History, Faculty of Arts and Sciences, East Tennessee State University, Johnson City, USA; \\ rankinj@etsu.edu
}

Received 1 October 2012; revised 19 November 2012; accepted 27 November 2012

\begin{abstract}
The paper evaluates the ways in which Hamilton, Ontario's three daily newspapers covered the influenza epidemic, 1918-1920. In Hamilton, the central aspect of influenza coverage was Dr. Roberts' decision to close all public meeting places twice during 1918 . No other story but those connected to a public meeting ban could sustain interest. Thus, the story for the press was to be the ban: whether to ban, what to ban, to lift or not, to re-impose. The story monopolized influenza coverage to such an extent that traditional threads, such as morbidity and mortality and personal interest stories, received little attention. The ban, because it restricted personal freedoms and involved local politics and commerce, received extensive coverage. In the absence of a ban, the influenza story could fade out of the press even during some of the most virulent periods of the epidemic. The paper finds that influenza was not transformative in Hamilton and in fact, demonstrated the viability of traditional charitable responses to disease. The actions carried out by Hamilton's Board of Health cannot be considered "modern" as its methods were more akin to the nineteenth century than those of the later bacteriological age.
\end{abstract}

Keywords: Influenza; 1918; Epidemic; Hamilton; Ontario; Health; Medicine

\section{INTRODUCTION}

This paper evaluates the ways in which Hamilton, Ontario's three daily newspapers covered the influenza epidemic, 1918-1920. Newspapers are a valuable way to gauge how a city and its citizens responded to a disease crisis. They also allow for an examination of the diffusion of scientific and medical ideas and provide insights into what the public could know and the style and tone with which this information was transmitted. Hamilton, Ontario possessed all the proper ingredients for an influenza epidemic to have a significant public impact. Led by its dedicated Medical Officer of Health (MOH) Dr. James Roberts, the city was sensitive to public health issues. The outspoken Roberts was a skilled manipulator of public sentiment, a talent employed to extract funding from a succession of fiscally conservative mayors [1]. There were three active daily papers in Hamilton, The Herald, The Spectator, The Times; each with its own political bent and boasting impressive daily circulation rates [2]. The presence of an active press and an even more dynamic $\mathrm{MOH}$ should have ensured that any health story was covered with both enthusiasm and in great detail, especially one as sensational as a worldwide pandemic. Although influenza received its due coverage, it was not reported with the same flair, editorial freedom, and sensationalism that characterized epidemic disease reporting in the nineteenth century [3]. In Hamilton the central aspect of influenza coverage was Dr. Roberts' decision to close all public meeting places twice during 1918. No other story but those related to a public meeting ban could sustain interest. Thus, the story for the press was to be the ban: whether to ban, what to ban, to lift or not, to re-impose. The story monopolized influenza coverage to such an extent that traditional threads, such as morbidity and mortality and personal interest stories, received little attention. In fact, morbidity and mortality rates were often only reported upon to either justify erecting a ban or employed as evidence to support removing the ban. Since it restricted personal freedoms and involved local politics and commerce, the ban received extensive coverage, often on the front page. In the absence of a ban the influenza story could fade out of the press, even during some of the most virulent periods of the epidemic.

\section{DISCUSSION}

In March 1918 physicians recorded the first cases of influenza among soldiers stationed at Camp Funston in 
Kansas. It is believed that American troops subsequently brought influenza to France, where the disease spread rapidly among combatants and civilian populations. During the summer of 1918, returning soldiers brought influenza to Canada [4]. In late September the first cases began to appear in Hamilton. Hamilton, a city of 110,000 residents, had a relatively large urban population, which had expanded rapidly during the late nineteenth and early twentieth century. The city profited from its accessible position on the west end of Lake Ontario, which attracted large industry. Formed in 1910 and 1912, steel manufacturers Stelco and Dofasco were large employers that represented Hamilton's expanding business and manufacturing center. Hamilton's industrial growth in general, but its focus on steel in particular, would rightly earn Hamilton the nickname of "Steel Town".

On 28 September, Hamilton's three major papers: The Herald, The Spectator and The Times, reported that returning soldiers had brought influenza across the Atlantic to the Royal Air Force armament school in west Hamilton [5]. Attempts to confine the disease failed; by 4 October influenza had spread to the general public. This threat was taken seriously by Dr. Roberts who ordered an emergency meeting of the Board of Health [6]. The five members of the Board of Health comprised some of Hamilton's most influential citizens. Members of the Board of Health included: the $\mathrm{MOH}$, the mayor, an alderman, the city controller, and was chaired by prominent citizen Norman Clark. It was during this meeting that Dr. Roberts, Hamilton's MOH and the vice-president of the American Medical Association, emphasized the serious nature of the disease. He warned those in attendance to prepare for a long fight [6].When influenza reached Hamilton in September 1918, Canada was without a national health department. The formation of a federal health department had been planned; however, it was not operational by the time influenza arrived on Canadian shores [7]. Responsibility could have fallen to a variety of departments, including Agriculture, Immigration, and the Marine department, all of which seemed unsure of whose task it was to stop influenza from entering Canada. In consequence, none of these departments took a leading role in preventing the spread of the epidemic [8]. The responsibility for keeping influenza out quickly became unimportant as the disease moved inland and became a provincial responsibility. In 1881, Ontario became the first province in Canada to create a permanent provincial Board of Health [9]. In 1918, the provincial Board was headed by Ontario's Chief Medical Officer, Dr. John W. S. McCullough. The rather limited resources of the provincial Board of Health could not effectively deal with a disease that rapidly spread to virtually every locality in Ontario. Thus, disease control in Canada very quickly changed from a federal responsibil- ity to a provincial problem, and then, finally, municipalities were charged with the power and responsibility to deal with influenza. Although this transition may have been unexpected, local Boards of Health were in a reasonable position to deal with the new challenge of influenza. The 1914 legislation passed in Ontario concerning the role of local Boards of Health and its medical officers had given municipal boards a considerable amount of power to order and enforce decrees that would protect public health. The most relevant section of the new Board of Health Act was Section 56, which read:

Where any communicable disease is found to exist in any municipality, the medical officer of health and local board shall use all possible care to prevent the spread of infection or contagion by such means as in their judgment is most effective for public safety [10].

With this power invested in the hands of municipal Boards of Health, their medical officers had the legal backing to take decisive action. The lack of a central agency capable of coordinating a nationwide response allowed for a variety of different measures to be employed across Canada. For example, authorities in Western Canada used quarantine and placarding of infested homes, whereas authorities in Hamilton judged these tactics to be ineffective and thus, they were rarely employed [8].

With influenza amongst the general public, Dr. Roberts was quoted in The Herald stating that he was contemplating closing all public meeting places to minimize the spread of contagion [11]. The press was a useful tool for public officials; not only did it provide Roberts with a method capable of reaching the public, it allowed him to "test" ideas and gauge reaction without promising or committing to a policy or plan. Ontario's Chief Medical Officer, Dr. McCullough, was asked to comment on Roberts' potential plan. McCullough explained that he opposed Roberts' proposal, stating that little value can be derived from such action. McCullough advocated a "hands off" approach for he believed that the public should not be forced to endure unnecessary restrictions [12]. Dr. Roberts proved his willingness, at least at this juncture, to heed the advice of the province's Chief Medical Officer and was quoted in The Herald stating that after further consideration he now opposed the idea of instituting any sort of restriction on the freedom of the public [13].

With a public meeting ban ruled out, Dr. Roberts undertook other initiatives to prepare Hamilton for what authorities believed would be a long battle with influenza. One of his concerns was the shortage of frontline workers and as such, he issued an appeal to nurses employed in the surrounding areas to come to Hamilton to aid in 
the fight against influenza. On 7 October, a few days after his initial appeal, The Herald reported that there had been little response to Dr. Roberts' plea [13]. Considering that many nurses were overseas tending to injured soldiers and that communities across North America were dealing with influenza, it is not surprising that Hamilton was unsuccessful in attracting help. As we shall see, Dr. Roberts' desire for additional frontline workers and other resources encouraged him to rely upon the community and traditional lines of charity to aid in the battle against influenza.

Each of Hamilton's three major papers participated in disseminating information from the Board of Health to the reading public. In fact, following a meeting of the Board of Health, these papers would often publish articles that contained condensed reports of the actual minutes of that meeting. This method of reporting ensured that although Hamiltonians had three major papers to choose from, the public often received similar influenza coverage no matter which paper they preferred. Despite the lack of variety, the relationship between the Board of Health and the press created a vehicle in which the public could have been, but often was not, informed of pertinent developments in the epidemic's progress.

Although influenza had spread to the general public, none of Hamilton's three presses expressed any real concern nor were there any attempts to play down or to sensationalize influenza. Even when the pestilence descended upon the city, neither the press nor the public demonstrated much concern. Instead, in absence of a more newsworthy thread, the press rather casually informed the public of the number of new cases and subsequent number of deaths that occurred each day. During the nineteenth century, yellow fever epidemics were often covered in great detail. Take for instance The New York Times, which covered yellow fever epidemics in the South as if every development could mean life or death for the people of New York. The public of New York feared yellow fever and the press' sensational reporting played upon this fear [14]. In Hamilton, there was little sensationalism or editorial voice. In the early days of October the press did not praise or criticize any actions undertaken by the Board of Health; it simply reported them. Nor did any of the editorials published by Hamilton's presses provide evidence that the public feared influenza. It was only later, and in response to a restrictive public meeting ban and an order limiting shopping hours, that Hamilton's presses expressed a particular viewpoint.

While Roberts had agreed to forgo a public meeting ban, he refused to sit back or adopt the "hands off" response advocated by Ontario's Chief Medical Officer. Concerned with the spread of influenza amongst the general public, Roberts issued an order that instructed theatre managers to remove patrons who were coughing or sneezing. He also excluded all visitors from the hospitals to prevent the spread of contagion. Furthermore, Roberts met with officials from Hamilton Street and Railway to make arrangements to improve ventilation and to prevent overcrowding in its streetcars. The Board of Health also organized a conference with local schoolteachers, so that teachers could be advised on how to best instruct their students on how to avoid contracting influenza [15]. Although Dr. Roberts had previously told the press that he would not interfere with the freedom of the public, some of his measures did restrict the movement of the sick and access to them.

On 12 October The Spectator announced that 500 new cases of influenza had been reported [16]. Four days later, the Board of Health held a meeting with local physicians to discuss the prospects of enacting a general meeting ban. During this meeting, Dr. Roberts admitted that he was reluctant to order a public meeting ban. Nonetheless, after discussing the matter with physicians, Roberts used his power as $\mathrm{MOH}$ to order a public meeting ban effective on 20 October. Roberts stressed to those in attendance that he had not been influenced by any outside source and that the decision to enact a ban was his alone [17]. However, when explaining to the press why the ban was implemented, Dr. Roberts attributed its creation to pressure from local physicians and unnamed leading businessmen:

I did not wish to be autocratic and in the view of the opinionof some of the medical men that the disease will take toll tothe extent of 1200 or 1300 persons [I] was willing to bow tothe majority of the medical profession as well as to the willof many leading business men [18].

Roberts had manipulated the situation perfectly. In city hall, where the Board of Health met, Dr. Roberts demonstrated that he alone was in control of the situation. In communication with the public via the press, Roberts rested responsibility for the ban on the shoulders of both local physicians and the Board of Trade, ensuring that any complaints would not be focused solely on him. By portraying himself as a reluctant character in the implementation of a general ban, Roberts ensured that the provincial authority would not have grounds for public disapproval. Although Roberts had an interest in appearing reluctant in imposing the ban, he was uncompromising in its strict adherence: "This order will be carried out even if it takes the whole police force to enforce it [19].”

The general meeting ban forbade the attending of all public meeting places, including pool-rooms, theatres, schools, and even churches [19]. The ban was contrary to the advice of Dr. McCullough, who would later criticize Roberts' methods. Roberts may have been spurred into action not only by the rising morbidity, but also by local 
physicians who predicted that influenza would kill 1300 Hamiltonians [18]. Given that this prediction appeared in the press, it is reasonable to assume that the reading public was aware of the seriousness of the situation. Indeed, the prediction of 1300 may have been placed in the press to gain support for the ban.

Roberts delayed implementing the ban until 20 October to give the public time to prepare and to allow the Board of Health to organize public meetings that explained how to prevent the spread of influenza [17]. The Board of Health judged public health meetings worth the risk of contagion: other meetings clearly were not. Although the ban may have been draconian in nature, its implementation was praised by members of the public who had become anxious for action. In fact, the origins of the ban lie with a joint plea from Hamilton's Board of Trade and local clergymen who had petitioned the Board of Health to impose a ban [20]. Roberts was able to use this plea from the public to make it appear that he, as an officer of the people, was submitting to their will.

The ban was erected at an inopportune time as it threatened to disallow an important civic event. During the Great War, communities across Canada held victory loan parades as a way of raising money for the war effort. Although victory bonds were sold throughout the year, it was during the parade that the most money was raised [21]. Dr. Roberts refused to sanction Hamilton's participation in the victory loan celebration due to the city's problems with influenza [22]. Victory loan officials were adamant that the parade be allowed and attempted to apply pressure by attending meetings of the Board of Health and by pleading their case to the provincial health authority [23]. At a meeting of Hamilton's Board of Health the victory loan delegation presented a telegram composed by the provincial secretary on behalf of the provincial Board of Health that stated, "it (the victory loan parade) should be allowed provided the gatherings are not large [24]." How could the provincial authority expect Dr. Roberts to impose a regulation that allowed for a parade but at the same time effectively limited the formation of crowds? It appeared that Roberts would either have to consent to the parade and allow people to congregate or use his statutory authority to cancel the victory loan parade. The provincial health authority appeared to force Dr. Roberts into a corner; either Dr. Roberts agree to allow the parade or else risk appearing autocratic and unwilling to compromise. On 29 October the victory loan matter was solved. The minutes from the Board of Health state:

that it (the ban) had served to prevent a spread of the disease; that he (Roberts) was not guided by outside cities in their actions-that the disease had not abated and in the interest of public health he refused to recommend to the Board of Health that permission be granted to hold public meetings owing to the danger to human life [24].

The minutes of the meeting end with the following terse statement recording the actions of the attending victory loan supporters, "the (victory loan) deputation in view of the circumstances as explained by the Medical Health Officer withdrew their request [24].” Dr. Roberts had once again defended his authority and control over Hamilton's response to influenza.

On 16 October, the same day that the public meeting ban was promulgated, the provincial Board of Health announced an important initiative that would shape Hamilton's ability to cope with the influenza epidemic. On this day, at a meeting of the Board of Health, Mrs. Harry Carpenter presented a telegram from the provincial secretary W. D. McPherson authorizing her to organize a local branch of the Ontario Emergency Volunteer Health Auxiliary. As the annual Health Report issued by Hamilton's MOH recounted, the purpose of this newly formed local branch was to,

enlist voluntary help for nursing, and to provide necessary rudimentary education in the care of the sick for those enlistedso that their services might be utilized to best advantage inemergency [25].

The Board of Health guaranteed Mrs. Carpenter their co-operation and offered to pay any expenses incurred in carrying out her duty [25]. Mrs. Carpenter proved to be an efficient leader who had a knack for recruiting volunteers to act as nurses. By 22 October, less than a week after its creation, The Herald reported that the Volunteer Health Auxiliary had one hundred volunteer "nurses" to aid in the fight against influenza [25]. In all, some two hundred women served in Hamilton as volunteer "nurses" during the epidemic. These women were called Sister of Service, or S.O.S., nurses [26]. In his annual report, Roberts praised this organization and its members:

One cannot speak too highly of the devotion of the S.O.S. nurses and their self-sacrifice, wholaboured early and late doing nursing and housework and the hundred and one things that only a women can do [26].

Hamilton's reliance on traditional forms of charity was widely acknowledged as effective. After the formation of the Volunteer Health Auxiliary there was little complaint of the lack of professional nurses or calls to reform local health services.

The local branch of the Imperial Order of the Daughters of the Empire (IODE) volunteered to provide food and other necessities to influenza sufferers. They also were willing to take up other tasks that influenza sufferers were not able to manage. This ensured that sufferers, especially those that lacked family support, had someone 
to take care of menial tasks such as cleaning and cooking. These were important tasks; ones that lay outside the purview of "modern" medical care. The IODE began their efforts on 19 October. Two days later they had made baskets of food containing; soup, jelly, custard, rolls, linseed tea (when ordered), cocoa, fruit, and other important necessities, that were ready to be shipped out to the suffering [26]. Funding initially came from City Council, which had provided a grant of two hundred dollars with promises of more money if needed. Thanks to public donations, the IODE did not require further funding. By the end of the year, the IODE reported that $\$ 2575.10$ had been donated to the cause. This helped the IODE to send out 5288 baskets to 721 homes by the end of January 1919 [26]. Traditional charity proved quite effective in alleviating the problem of getting food to the sick and housebound. The city and the Board of Health themselves did nothing of this nature. Hamilton's response to influenza was not new or modern. The triumphs of bacteriology and the increased understanding of disease did not result in new or more effective preventive techniques that could be applied to an influenza epidemic. In fact, Hamilton's response can be equated with the nineteenth century, insofar as the health authorities relied on traditional charitable organizations to take care of the sick. The public was the main contributor to "patient" care; not the city.

To most observers the response to influenza had worked and by 1 November it appeared that influenza was dying out [27]. While it is difficult to judge public sentiment, the press began to publish articles suggesting that the ban would soon be lifted. According to these articles, with the disease in decline Hamiltonians were clamoring for the removal of the ban. On 1 November, with the Board of Health under scrutiny, Dr. Roberts responded to his critics by telling The Spectator, "the riffraff will damn us whatever we do, but I believe that all good people are behind us [27].” Despite the comments, the Board seemed to take heed of public sentiment agreeing on 4 November, "to lift the ban on schools, assemblies, churches etc. at 12:00 p.m. 9 November [28].” On 10 November, with influenza on the decline and the ban, which had lasted 25 days, lifted, public life returned to normal.

The ban was the central feature and focus of influenza reporting. Without these restrictions, influenza disappeared from the press for over a week even though the disease continued to afflict and kill Hamiltonians. Once the ban was removed people began to fall into old patterns and the disease appeared to profit from the return to normalcy [26]. On 13 November influenza reappeared in the press with both The Spectator and The Herald publishing the exact same plea from Dr. Roberts, who warned the public against, being lulled into a false security. The epidemic is still serious as may be seen from the large number of deaths reported from day to day and there should be no diminution of precautions on the part of the individual citizen [29].

Dr. Roberts once again employed the press to communicate his perspective to the public. He clearly judged the press an effective tool of communication and that some of his messages would appear in more than one paper, unedited, shows the press found his directions and perspective important and newsworthy.

On 14 November citizens throughout allied countries rushed to the streets to celebrate the news of the armistice. On that same day, Roberts, who was not pleased to see these mass celebrations, reminded Hamiltonians that other cities were still enforcing public meeting bans and that he would not hesitate to reinstate restrictions if the public was not going to be more cautious [30]. The following day, The Spectator reported that there was a sharp increase (134) in the number of new influenza cases [31]. Dr. Roberts blamed the recrudescence of influenza on the recent celebrations. He further stated that any subsequent mortality could not be attributed to the actions of the Board of Health for it was powerless to stop such celebrations: "The recrudescence of the disease was caused entirely by conditions which we had no control (over). A machine gun could not have dispersed those crowds [31].”

On 15 November, Roberts, who had only three days ago threatened to re-impose a ban, told the press he did not believe another ban would be necessary: "Other places are getting on without the ban and probably we will be able to do so too [32].” What prompted Dr. Roberts to completely change his perspective within three short days is unknown. Is it possible that influential people or groups in Hamilton convinced him to reconsider his position on re-imposing the ban? Once Roberts had assured both the press and the public that he was against issuing another ban, influenza once again drifted out of the press. The press simply did not have an interest, and must have judged neither did its audience, in stories concerning mortality and morbidity rates. Even in November 1918 when the disease claimed its second highest number of victims (only the previous October had proven more deadly), there was little interest in stories that pertained to the disease's development. Had Hamiltonians been afraid of influenza, surely there would have been more coverage of the progress of the disease. Hamiltonians' decision to partake in the mass celebrations held on 14 November suggests that the public was not afraid to risk contracting influenza.

On 23 November, a bitter dispute between local physicians and Dr. Roberts placed influenza back into the news. Physicians complained to The Herald that they 
were being ignored by the Board of Health which refused to meet with them to consider the necessity of further restrictions [33]. Influenza on its own was not considered noteworthy. As part of a personal interest story however, especially one that pitted physicians against one another and offered the possibility of another ban, influenza was judged newsworthy. These unnamed physicians complained that the Board of Health continued to maintain that influenza was dying out, even though physicians were treating approximately 40 "flu" patients every 24 hours [34]. When asked to comment on the relationship between the Board of Health and local physicians, Dr. Roberts called these medical practitioners, "a lot of old women and sissies who were trying to run the city [35]." Roberts' statement did little to diffuse the situation and this conflict ensured that the fledgling story of influenza remained in the news. As the death rates continued to rise (165 Hamiltonians died in November), The Herald broke its editorial silence and took a stance on the influenza issue [36]. The paper believed it necessary to convey to the public the importance of following the advice of the Board of Health: "Let us consider that there are people dying here every day who might and probably would have lived but for the removal of the former restrictions in compliance with popular demand [37]." Although Roberts stated that no outside forces influenced his decision, The Herald suspected it was public sentiment and not proper medical judgment that led to the premature removal of the ban. Whether Dr. Roberts encouraged The Herald to run a piece calling for restraint is unknown.

On 29 November, after a total of 165 deaths for the month, Roberts ordered the erection of another ban. On this day The Times reported:

By an unanimous decision, after almost four Hoursof discussion the Board of Health and a special committee of local physicians would re-impose a banon public gatherings until the disease, in the opinion of the health authorities, is under control [38].

In addition to the regulations contained in the first ban, the Board of Health issued an additional measure that forced businesses to close their doors at 4 p.m. The Board of Health also suggested, but did not order, that the city's large industrial manufacturers reduce the spread of contagion by having their employees go to work in relays arriving at 7, 8, and 9 a.m. and quitting at 4, 5, and 6 p.m. to avoid congestion on public transit [38]. Dr. Roberts recounted his disposition to The Spectator the morning of the war celebrations, explaining how disappointed he was in Hamiltonians for not heeding his advice:

I got up that morning in a very serious temper. The folksin the house asked me if I was not going up town tocelebrate, and I told them I was not; that I was going to stay at home and not die before my time came [39].

Dr. Roberts then reminded the public of his previous warnings to stay away from crowds: "I issued a warning then that people would pay dearly for their foolishness, no matter how great the cause that would justify a celebration. They have paid for it, and are paying for it [39].”

The day after the 4 p.m. ban was announced members of Hamilton's business community were quoted in The Herald stating their opposition to the 4 p.m. closing order. Merchants argued that if Dr. Roberts must do anything he should not restrict, but rather extend shopping hours. They argued that by extending business hours, the Board of Health could ensure that less people were crowding into stores at the same time [40]. All three of Hamilton's presses would publish, over the next few days, articles questioning the logic of the 4 p.m. closing order. The Board of Health refused to admit any mistake and did not explain that the order was probably intended to reduce congestion in the streets and did not take into account additional crowding in stores. The purpose of the 4 p.m. closing order was likely to ensure that shoppers were not on the streets and in the streetcars at the same time as workers were beginning to make their way home. By enacting the 4 p.m. closing order, Dr. Roberts had lost the sympathy of the press which may have refused to print, or at least did not solicit, an explanation from the Board concerning the reason for the closing order. By losing the support of the press, Roberts had lost his link to the general public. The 4 p.m. closing order encouraged The Times to break its editorial silence, calling these restrictions: "very unfortunate and harmful." The article asserted that the restriction on shopping hours: "drives crowds into stores between 2 and 4 o'clock... The four o'clock rule is a menace to public health and a hardship on the merchants and the people alike [41].” The restriction on shopping hours had encouraged business interests, the press, and the public to question the competence of the Board of Health. It is not surprising that once commercial interests, whose advertisements constituted a significant part of the presses' income, began to challenge the wisdom of the closing order, that the press reconsidered its own position. In fact, the change in attitude by the merchants was mirrored by an exact change in the outlook of the press. Public opinion remained muted. Although there were articles complaining about how unjust it was to shorten shopping hours during the Christmas season, these articles were from the perspective of merchants, not consumers [42]. The Board of Trade likely pushed for the first ban hoping that its implementation would restore confidence and keep the public spending. They were likely aware that although the ban may cut profits at first, in the long run, a healthy 
city would prove most profitable. However, once a ban was erected, and the epidemic had settled into a pattern, the ban had no good news for commerce. The implementation of a second ban, which had little to do with restoring confidence as Hamiltonians demonstrated no real fear of influenza, threatened commercial profits. After the implementation of the second ban, The Spectator became the most critical newspaper of the Board of Health. It created a section of the paper entitled Knutty Points where the public was encouraged to write in and comment on sections of the ban that they disagreed with. Knutty Points was intended to be comical, with authors selecting whimsical names such as Eva Kauff. Most of the complaints were based on the closing order, illustrating that Hamiltonians either did not understand the purpose of the 4 p.m. ban or felt it to be unnecessary [43]. Knutty Points was one occasion where the public was able to voice its own perspective. Given that Knutty Points was supposed to be humorous suggests that Hamiltonians were not afraid, nor likely to be offended by articles that poked fun at the Board of Health and influenza.

The second ban also received little support from Hamilton's religious communities. Various denominations and their parishioners were outraged that a ban had been placed upon churches, especially during the month of December. On 4 December the Board of Health fined a Catholic Priest, the Rev. Thomas Tarasiuk, rector of St. Stanislaus's Polish church, twenty dollars for ignoring the ban and holding regular church services [44]. Forcing a ticket upon a priest did little to encourage understanding between Hamilton's religious community and the Board of Health. After the fine was levied there was an effort to undermine the authority of the Board of Health. Bishop Clark led the attack against Dr. Roberts, stating that Board of Health had not taken the proper precautions and hinted that the Board of Health, not the public, was responsible for the recrudescence of influenza [45]. Defiant Catholic clergy, who pledged to ignore the ban and hold Sunday service, were silenced after a high ranking Catholic official, His Lordship, Right Rev. T. J. Dowling, instructed that all public services would be cancelled until the removal of the ban [46]. After the announcement that the Catholic hierarchy would adhere to the ban, the other denominations followed the order. This was a major victory for Dr. Roberts reinforcing his authority and control over the situation.

December proved a difficult month for the Board of Health. Roberts, tired of the constant scrutiny, was quoted in The Herald stating:

We are doing what is considered best in the interests ofthe whole city and so not propose altering our set plans onewhit to meet the wish of every Tom, Dick or Harry, who has nothing better to do then to throw obstacles in the path of duty. I am confident we have the hearty co-operation of all intelligent citizens, without which we can never hope to rid Hamilton of the epidemic, which is now in our midst [47].

The driving force behind Hamiltonians complaints, as articulated by the press, was that they were not afraid of influenza and could not understand why so many restrictions were necessary when the disease was not proving as deadly as the authorities predicted. They also could not see the value in the 4 p.m. closing order. In the early days of the epidemic, the public was instructed to brace for what was promised to be a terrible year, one of pestilence and fear. This sense of danger was conveyed to the public by the press, the Board of Health, and the Board of Trade, who all found it advantageous, at least at the time, to emphasize the threat of influenza in hopes of securing obedience, to create a bigger story, or to gain support for a public ban. When the disease did arrive, it compared nothing to the death and destruction that Hamiltonians came to expect. By November it appeared that the authorities had over-reacted and that the severity of crisis promised would not be realized [18]. A 4 p.m. closing order which coincided with the Christmas shopping season proved to be a mistake; this placed the press, religious groups, business interests, and members of the public against Dr. Roberts and the policies of the Board of Health.

The erection of the second ban on 29 November in conjunction with the 4 p.m. closing order prompted each of Hamilton's three major newspapers to adopt a style of commentary that allowed for more editorial criticism. This change in policy resulted in the publication of articles that criticized the methods of the Board of Health. As mentioned, The Spectator emerged as the most vocal critic of the ban, focusing its attacks on the Board of Health. The press explained that of the five members who comprised the Board of Health, only Dr. Roberts had received medical training and, in an attempt to undermine the authority of the Board, had begun referring to its members by their former occupations, stating that this group consisted of a tailor, a plumber, a lawyer, a boat builder, and only a single doctor [48]. These attacks were located on the front page to be read by almost everyone who picked up the daily run. The Herald claimed that the Board of Health was acting "unilaterally" and in a "pompous" manner. To undermine the credibility of the Board of Health, The Herald compared Hamilton's more restrictive and increasingly unpopular measures to other Canadian cities that employed less intrusive forms of disease prevention [49]. The interest in the ban and lack of concern over the spread of influenza suggests that Hamiltonians were more concerned about the restriction of their freedoms than with the spread of influenza. In 
fact, the papers rarely published any information concerning the number of influenza cases during December, except when these statistics were used as examples as to why the ban should be lifted [50].

It is noteworthy that all three Hamilton papers revoked their support for the ban in early December. One reason could be that the press had become aware that the public was losing support for the ban and adjusted their attitude accordingly. Another contributing factor could be the economy. Hamilton's economy could have survived a brief ban that restored consumer confidence, but a long one which included a 4 p.m. closing order could jeopardize the city's commercial profits. The merchants, whose advertisements fueled the presses profits, may have encouraged the press to print articles that were critical of the ban. Without a push from commercial interests, it is hard to imagine that an order that closed stores a few hours early would have elicited so much criticism. Hamilton's presses were more concerned with the reduction in shopping hours than they were with the restrictions placed on attending church or any other type of gathering.

On 16 December the Board of Health lifted Hamilton's second and final public meeting ban. The Board of Health was at pains to make it clear that the ban was lifted, "not because of any pressure from outside but because rigorous restrictions are no longer necessary [51]." The Herald, most likely alluding to the 4 p.m. closing order, stated, "should there be another serious recurrence of the epidemic, we suggest that preventive measures different from those which have been enforced, should be tried [51]." On the following day The Spectator used the example of the large crowds that flocked to shopping outlets as evidence that the, "drastic restrictions of the Board of Health were (until now) choking Christmas trade [52]." This action also demonstrates the lack of public fear of influenza for the moment the ban was lifted Hamiltonians did not hesitate in returning to normal. Following the removal of Hamilton's second ban, Ontario's Chief Medical Officer, Dr. McCullough criticized Dr. Roberts' methods by stating that public health bans were useless and that public health officers should not adopt such "fussy" measures [53].

Although Spanish influenza would continue to infect Hamilton's population for another two "flu" seasons, without a ban or the threat of a ban, influenza lost most of its newsworthiness. The press casually covered the recurrence of influenza but only partially and with little enthusiasm [54]. Even in February 1920, when there were 3505 active cases, the press had little to say about influenza, returning instead to its previous method of reporting the number of cases without any editorial stance [36]. After the repeal of the second ban there is no evidence that Dr. Roberts ever considered erecting a third ban. It seems that Dr. Roberts had adopted the earlier "hands off" approach advocated by Dr. McCullough. By 1919 Hamilton had returned to normal. In fact, the Canadian Annual Review of 1918, which evaluates the events of the year before, only dedicated one page of commentary to influenza: the war was covered in great detail and occupied most of the edition [55]. In the 1919 edition, influenza proved forgettable; not even worthy of a single mention [55]. Although the public generally adhered to the ban, they did not follow any of Roberts' advice once a ban was lifted. When Roberts removed the first ban, he still cautioned the public against congestion, hinting that such actions could prove deadly. Despite his recommendations, thousands still rushed to the streets to celebrate the armistice. Immediately following the ending of the 4 p.m. closing order, Hamiltonians did not shut themselves at home but instead flocked to shopping outlets. This sort of action suggests little fear and that the public was only willing to alter the patterns of life when ordered to by a public health ban. In Hamilton there was no evidence that the sick were being shunned or that people were overly concerned with those who had exhibited flu symptoms. There were no editorials calling for actions against the sick. After the erection of the second ban, popular public sentiment argued that it was best to end the ban, return to normal, and wait for the disease to die out.

The influenza epidemic of 1918-1920 did not result in mass panic. In Hamilton, the public completely lost interest in the story of the progress of the disease and its corresponding death rate. There are two likely reasons why Hamiltonians remained calm. The first reason is psychological. The flu was a seasonal disease with which Hamiltonians were familiar. Although Spanish influenza was much worse, it still was not a new disease and thus, did not inspire fear of the unknown. John Duffy, a historian of American public health, states that: "strange and unfamiliar diseases have always aroused far more consternation than the more deadly and debilitating familiar ones [56]." Because of their relationship with other strains of influenza, Hamiltonians were not as afraid of Spanish influenza as they might have been if the 1918 pandemic was caused by a different, completely unknown, disease.

Another reason that Hamiltonians avoided mass panic was the relatively low mortality rate. Precise figures are problematic: Influenza was not a reportable disease and its close connection with other ailments makes analysis difficult [57]. Mortality estimates for Hamilton during the three most deadly months (October to 31 December 1918) vary from 635 to 418 [58]. These three months account for the overwhelming majority of influenza mortality in Hamilton. If we employ the recently revised number of 418 deaths, during its height influenza had a 
mortality rate of 3.8 per thousand. This is significantly lower than the 6 deaths per thousand estimated as the combined national averages for Canada and the United States [59]. The public was made aware that they had gotten off relatively light in comparison with other Canadian cities. For instance, on 9 December 1918, The Herald ran a piece demonstrating that Hamilton had a significantly lower mortality rate than Montreal, Halifax, Toronto, and Ottawa [60]. This lower level of mortality can explain, in part, the absence of public fear or any sign of mass panic.

So why did Hamilton escape the worst clutches of this pandemic? Was it the work of Dr. Roberts, his general meeting bans, and the 4 p.m. closing order? These restrictions, in conjunction with the relay system, starting and ending workers at staggered times, did reduce congestion on the streets and in the streetcars. The reduction of congestion may have helped, but likely had little impact on the course of the epidemic. It appears that seasonal changes, more so than health precautions, caused the disease to flare up and decline in strength. However, this does not explain why other Canadian cities sustained higher levels of mortality. Additional research and comparable study may shed light on this question although we may never know why other communities suffered higher mortality rates.

\section{CONCLUSIONS}

Scholars maintain that health officials across the globe implemented a top-down approach to combat the influenza virus. In fact, some scholars view influenza as a stepping-stone in the further bureaucratization of medical services which contributed to the creation of a Canadian federal health department in 1919 [61]. In Hamilton, it was difficult to get away from the name of Dr. Roberts. Given his position in Hamilton's medical community and the status granted to him by the press it would be easy to conclude that disease prevention in Hamilton was carried out in a top-down manner. However, a close analysis of the events demonstrates considerable grassroots participation. In fact, the impetus for the erection of the first ban, at least in part, originated amongst a segment of the population. Traditional charity made a real and valuable contribution by taking care of those who were too ill to look after themselves. Physicians and professional nurses were obviously very important; however, their numbers were stretched so thin that they had little time for each patient and even when they were with a patient, they could do little to ease their pain. Women's organizations on the other hand provided food and were able to do the chores that influenza sufferers could not complete themselves. This must have made the recovery period, for a large percentage of the sick, much easier and may have forged new and stronger community ties [21].
Spanish influenza killed some 20 to 100 million people worldwide [62]. Alfred Crosby famously asserted that despite its deadliness, influenza was a "forgotten pandemic". According to Crosby, influenza tended to be seen as a small part of the much bigger and memorable story of WWI [63]. Although the deadly scourge did attack Hamilton, the mortality, as compared to other Canadian cities, was relatively low. A few prominent people, including physicians, did die. However, at least at the local level, influenza had little lasting impact on Hamilton. There were no sweeping policy changes, or even a significant increase in funding for the Board of Health. In Hamilton, influenza was not transformative and in fact, demonstrated the viability of traditional charitable responses to disease. The actions carried out by the Board of Health cannot be considered "modern" as its methods were more akin to the nineteenth century than those of the later bacteriological age. While Hamilton's response to influenza had much in common with the nineteenth century, the press and the way it was reported were very different. Unlike with some nineteenth century presses, newspaper coverage in Hamilton included very little editorial stance or sensationalism meant to elicit concern. After influenza died out, Dr. Roberts continued to fight with the provincial authorities and in fact, had another major contest with local physicians and city counselors who refused to give him a raise in salary. Dr. Roberts would continue to serve Hamilton as its $\mathrm{MOH}$ until his death in 1941 [1]. Influenza in Hamilton was not spectacular. The erection of the two general meeting bans and the 4 p.m. closing order proved to be the most newsworthy topics and the controversy surrounding these restrictions sustained and monopolized influenza coverage. It was this conflict, especially during the final ban, which ensured that influenza remained upon the front page. One has to wonder if Dr. Roberts had been less animated, or had the ban been less restrictive, would influenza have had the same newsworthiness? The press, in the absence of an interesting influenza related story could neglect to report upon the progress of influenza. So what do we make of this forgotten pandemic? Given the low levels of death and lack of significant local impact upon the city, Hamiltonians can be forgiven for forgetting.

\section{REFERENCES}

[1] Roberts, J. (1992) Dictionary of Hamilton biography vol. III. W.L. Griffen Printers Ltd., Hamilton, 176.

[2] Rutherford, P.A. (1982) Victorian authority: The daily press in late nineteenth-century Canada. University of Toronto Press, Toronto.

[3] Rankin, J. (2006-2007) For disease reporting in the Anglo-America press at the turn of the twentieth century see. The Reporting of Mosquito-Vector Disease in AngloAmerican Daily Press, Media History Monograph, 9, 1. 
[4] MacDougall, H. (2006) Toronto's health department in action: Influenza in 1918 and SARS in 2003. Journal of the History of Medicine and Allied Sciences, 62, 62.

[5] (1918) Influenza is reported in West Hamilton. The Spectator, 28 September, 18.

[6] (1918) Board of Health Minutes, 5 October.

[7] Pettigrew, E. (1983) The silent enemy: Canada and the deadly flu of 1918. Prairie Books, Saskatoon, 13.

[8] Lux, M. (1997) The bitter flats: The 1918 influenza epidemic in Saskatchewan. Saskatchewan History, 49, 4.

[9] Bliss, M. (1991) Plague: A story of smallpox in Montreal. HarperCollins, Toronto.

[10] (1914) Ontario Board of Health Act, Section 56.

[11] (1918) Four deaths from "flu” reported Here. The Herald, 5 October.

[12] McCullough, J.W.S. (1918) Four deaths from "flu” reported here. In: McCullough, J.W.S., Ed., The Control of Influenza in Ontario. Canadian Medical Association, Ottawa, 10841085.

[13] (1918) Nine more deaths from Spanish "flu”. The Herald, 7 October.

[14] Rankin, J. (2003) Public health quarantine in the American and British daily press, 1850-1905. Unpublished Manuscript, 10-13.

[15] (1918) Board of Health Minutes, 7 October.

[16] (1918) Week's toll of influenza five hundred cases. The Spectator, 12 October, 1.

[17] (1918) Board of Health Minutes, 16 October.

[18] (1918) Rigid shut-down is demanded by board. The Spectator, 16 October, 1.

[19] (1918) Will close all public places next Monday. The Herald, 16 October.

[20] (1918) Health board will stand by closing order. The Spectator, 16 October, 1.

[21] Jones, E.W. (2003) Searching for the springs of health: Women and working families in Winnipeg's 1918-1919 influenza epidemic. Ph.D. Dissertation, University of Manitoba, Winnipeg.

[22] (1918) Victory loan mass meeting is prohibited. The Spectator, 25 October, 1.

[23] The victory loan officials attended all board of health meetings from 24 October until the 29 October when the matter of a parade was conclusively settled. Board of Health Minutes for Hamilton 1918, 24 October, 28 October, and 29 October.

[24] (1918) Board of Health Minutes, 24 October.

[25] (1918) 100 Volunteer nurses soon ready to help. The Herald, 16 October.

[26] (1918) Annual Health Report, 31 October, 5.

[27] (1918) Epidemic passing. The Spectator, 1 November, 1.

[28] (1918) Board of Health Minutes, 4 November.

[29] (1918) Warning from doctors about the epidemic. The Herald, 13 November and (1918) "flu" epidemic is still serious. The Spectator, 13 November, 15.
[30] (1918) Ban on public gathering is again urged. The Spectator, 14 November, 1.

[31] (1918) Ban not placed on gatherings. The Spectator, 15 November, 31.

[32] (1918) "Flu” spreading. The Herald, 18 November.

[33] (1918) Doctors declare war on Hamilton's board of health. The Herald, 23 November.

[34] (1918) Doctors demand an apology or resignation of Dr. Roberts. The Times, 23 November.

[35] (1918) Health board not worrying about medicos. The Spectator, 23 November, 31.

[36] (1920) Annual Health Report, 47.

[37] (1918) A warning. The Herald, 27 November.

[38] (1918) Closing order goes into effect to-night. The Times, 29 November.

[39] (1918) Board of health ties up Hamilton during season approaching to Christmas. The Spectator, 29 November, 1.

[40] (1918) Merchants say order defeats its purpose. The Herald, 30 November.

[41] (1918) Four o'clock hour proves a menace instead of a help. The Times, 29 November.

[42] (1918) Mere mulishness. The Herald, 9 December.

[43] (1918) Knutty points. The Spectator, 4 December 1918, 12.

[44] (1918) Catholic priest was fined in court this morning. The Spectator, 4 December, 1.

[45] (1918) Will prosecute a priest for holding service. The Herald, 4 December 1918.

[46] (1918) Churches closed by bishop's order. The Herald, 7 December 1918.

[47] (1918) Order does not stop meetings at city hall. The Herald, 7 December 1918.

[48] (1918) As to the ban. The Spectator, 7 December, 1.

[49] (1918) Closing order to be modified. The Herald, 7 December.

[50] (1918) Fewer Deaths and Fewer Cases of Influenza. The Herald, 16 December.

[51] (1918) The ban lifted. The Herald, 16 December.

[52] (1918) Board silent about high-handed action. The Spectator, 17 December, 1.

[53] (1918) Ban on churches and theatres ill advised. The Herald, 20 December.

[54] (1918) More Flu. 14 February and (1919) flu deaths. The Herald, 4 April.

[55] (1919) The Canadian annual review of public affairs. The Canadian Annual Review, 574.

[56] Duffy, J. (1993) From humors to medical science, 2nd Edition, University of Illinois Press, Champaign, 5.

[57] MacDougall, H. (2006) Toronto's health department in action: Influenza in 1918 and SARS in 2003. Journal of the History of Medicine and Allied Sciences, 62, 63.

[58] Herring, D.A. and Korol, E. (1918) The north-south 
divide: Social inequality and mortality from the 1918 influenza pandemic in Hamilton, Ontario. In: Fahrni, M. and Jones, E.W. Eds., Epidemic Encounters: Influenza, Society, and Culture in Canada, UBC Press, Vancouver, 102-103.

[59] Herring, D.A. and Korol, E. (1918) The north-south divide: Social inequality and mortality from the 1918 influenza pandemic in Hamilton, Ontario. In: Fahrni, M. and Jones, E.W. Eds., Epidemic Encounters: Influenza, Society, and Culture in Canada, UBC Press, Vancouver, 98.

[60] (1918) Death rate in Hamilton under average. The Herald,
9 December, 4.

[61] McGinnis, J.D. (1981) The impact of epidemic influenza: Canada 1918-1919. In: Shortt, S.E.D., Ed., Medicine in Canadian Society, McGill-Queens University Press, Montreal, 471-472.

[62] Kolata, G. (1999) Flu: The story of the great influenza pandemic of 1918 and the search for the virus that caused it. Simon and Schuster, New York, 7.

[63] Crosby, A.W. (1990) America's forgotten pandemic. Cambridge University Press, Cambridge, 1990. 